\title{
The Role of Governmental and Non-Governmental Institutions and Associations on Women's Empowerment in Najran, KSA
}

\author{
Suhail Mahmoud Al-Zoubi and Majdoleen Sultan Bani Abdel Rahman \\ Department of Special Education, College of Education, Najran University, Kingdom of Saudi Arabia
}

\begin{abstract}
This study aimed at revealing the role of governmental and non-governmental institutions and associations (GNGIA) on empowerment programs of divorced, widows and spinsters women. To achieve the objectives of the study a questionnaire was developed which distributed to (78) male and female who are working in (12) governmental and non-governmental institutions and associations in Najran, Kingdom of Saudi Arabia. The results indicated a weakness in the contribution of GNGIA in empowerment programs for divorced, widows and spinsters for Saudi's Women.
\end{abstract}

Keywords: empowerment; Saudi's Women; governmental and non-governmental institutions and associations

\section{INTRODUCTION}

The past years witnessed the birth of concepts that occupied a significant role in the field of development, which were related to women's development programs. The gender and empowerment are concepts and terminology that have become rules in the strategies and the policies of countries and civil society organizations in the world. In fact, empowerment is a central definition which aims to build an alternative vision of development. It contains liberation and empowerment of the oppressed people in order to control their own future. Hence, it is the ultimate goal of an equitable and just society (Nikkhah, Redzuan and Abu-Samah, 2010)

Floyd (2005) Emphasizes that the empowerment means enhancing spiritual, political, social, educational, economic, and gender strength of individuals and communities. The empowerment aims to expand the capabilities and potential of individuals to engage in relevant institutions that affect in their lives, as well as to allow individuals to monitor these institutions (Narayan, 2002). Ahmed and Khalid (2012) indicated that the empowerment is well suited to deal with social change in general and with inequitable structures in particular. It provides people, communities, and organizations with the compulsory skills, confidence, and countervailing power to deal effectively with social change in a world that distributes needs, resources, and power unequally. The environment, that is empowering women, is important in serving individuals, families, and communities to increase their personal, interpersonal, socioeconomic, and political strength and increase influence towards improving their circumstances (Drower, 2005).

Many governmental and non-governmental organizations have adopted the principles of women's empowerment as a strategic objective for these organizations, where empowerment is associated elements in the development based on productivity, sustainability and social justice (Oyelude and Bamigbola, 2012). Thus, empowerment is recognition of the active role of women in the overall development.

Today, there is an urgent need for the implementation of women's empowerment programs in order to make them understand their rights and duties. Therefore, gender-based discrimination is a violation of the primary rights of women which enable legal security; consequently the community should be aware of women's empowerment programs that have a positive impact on the family, society and the whole country, perhaps that social and cultural constraints stands as an obstacle to women's empowerment (Jabeen \& Jabeen, 2013). Women's empowerment is the process in which women individually and collectively become active and obtain knowledge. So, Women's empowerment refers to a strategy to achieve gender equality as well as to the inherent capacity building processes for women (Suja, 2012). Additionally, the political decision-makers must support initiatives that aimed at gender equality in the areas of educational, political, economic and social.

The empowerment gives women the freedom to choose activities that aimed at improving the quality of their living. The beneficiary of empowerment programs are not only women, but also all sectors of the society (Dito, 2013). In addition the empowerment may vary from one to another community, but in general it refers to an individual's ability to be a productive and active member in the community. On the other hand, there is an agreement among researchers that the concept of women's empowerment focuses on indirect indicators of women autonomy such as decision-making, mobility, economic self-reliance, access to economic resources, and legal rights to equal treatment, inheritance and protection against all forms of discrimination. Additionally, eliminating all barriers that prevent the participation of women in the fields of employment, education, social, psychology, politics and economics (Charmes and Wieringa 2003; Suja, 2012; Moyle, Dollard, \& Biswas, 2006; Panigrahy, 2006; Mosedale, 2005; Arum, 2010). 
According to the United Nations Development Fund for Women (UNIFEM), the essential principle of women empowerment is equality in business, workplace, market place and community, this principle is a prerequisite for any society regarding empowering women. On the other hand United Nations Global Compact's report describes a group of rules and principles for the empowerment of women, including: Establishing a high level of cooperative leadership for gender equality, treating all women and men fairly at work, respecting human rights and non-discrimination, promoting education and training, providing professional development for women, implementing enterprise development, and marketing practices that empower women (Bukhari and Asim, 2013).

Al-Kharouf and Al-Hadidi (2011), Najm (2013) and Niraula (2011) approved that the women's empowerment programs included the psychological, cognitive, economic and political domains. The psychological domain is the feelings that individuals are competent, worthy of better conditions and capable of taking action on their own; the cognitive domain is the knowledge of one's social reality and the mechanisms that makes it functions the way it does; the economic domain is an access to independent means of support, which helps to make individuals more autonomous in their decisions; the political domain is the gaining of the skills to participate in and modify the institutions and policies of one's community or nation.

\subsection{Arab women's empowerment programs}

In the Arab world countries there are variations in the economic, cultural and political fields. However, religion of Islam and the Arabic language are the common denominators that unite of Arab Countries. Though, the Islamic religion encourages the participation of women in society, the Quran and the diligence Sunnah, provided a model for the role and status of women in society by showing their rights and obligations, whether they are mothers, daughters or wives. The last few years have witnessed interest by decision-makers and civil society institutions to activate the role of women in the comprehensive development programs (Weinberger, 2001). ). For that reason, the participation of women in development is one of the indicators measured by the progress of nations.

In the Arab world, the Arab Human Development Report indicated that human development in the Arab countries is suffering from weakness in the public freedom, weakness in the empowerment of women, and the weakness of the knowledge (Najm, 2013). Consequently, the empowerment of women became among the strategic goals and objectives in the Arab world for the construction of human development, and the liberalization of the women's potentials in the context of equality, justice and fairness. Recently, the Arab society needs to make further efforts in women's empowerment programs, investment capabilities and potentials. Accordingly, we find that associations, institutions, organizations, governmental, and nongovernmental organizations adopted the concept of empowerment as one of the strategies of women's human development in order to develop their capabilities in the fields of education, economic and social (Abdel Jawad, 2009).

In this context, the Arab Women's Organization (AWO) is an Arab governmental organization that deals with women working under the umbrella of the Arab League. The AWO is a concrete example of the importance of joint Arab action in the field of development and the empowerment of women and to highlight their role in building community. Furthermore, the AWO seeks to move towards the pursuit of programs and projects that empower Arab women through short and long term objectives strategies. The AWO also seeks through conferences and seminars which were held in many Arab countries to achieve political, educational, social, psychological and economic of Arab women's empowerment.

The Kingdom of Saudi Arabia is one of the Arab countries, which working through its development plans in the current and future highlight the role of women in society and their effective contribution in the political, educational, social, and economic domains ( Fatany, 2007). Thus, the rights of women in Saudi Arabia are derived from customs and traditions of Islamic religion, which provides equality between men and women in rights and duties. Women in the reign of King Abdullah Bin Abdulaziz Al Saud gained advantages and rights which have contributed to promote the status of women. Moreover, there are strategic plans by the government to empower women to move forward in the development of their skills as half of the society. Observers inside and outside of the Kingdom of Saudi Arabia agreed upon that Saudi women in the reign of King Abdullah Bin Abdulaziz, living their golden age, where the king always seeks to honor the women in various national events. Basically, the ruling regime in Saudi Arabia is based on the tolerant teachings of Islam which based on the foundations of justice and equality between men and women in rights and duties.

In the educational empowerment, women in Saudi Arabia have achieved significant gains in higher education and school education, whether in joining school programs or higher education, as well as opening scholarship programs to women inside and outside the Kingdom in order to obtain different academic certificates from various universities in the world. In the area of political empowerment women have taken over political and leadership positions in a number of institutions and government ministries, in addition to their distinguished presence in the Council of Shura (parliament). Regarding the social empowerment women have 
made gains in community participation, media and their right at work (Sahbani and Abbas, 2013). In the economic empowerment Saudi government has issued a series of laws and regulations relating to the empowerment of women by increasing their economic contribution in investment, employment, establishing a National Commission for Women's Affairs, facilitating access to licenses to practice professions and various economic activities, as well as facilitating the procedures for the establishment of women's industrial projects and training on administration these projects by collaboration with the Human Resources Development Fund.

In Kingdom of Saudi Arabia, there are a number of institutions, associations, and governmental and non-governmental organizations that provide services for the empowerment of women in economic and social domains, including: Alwaleed Bin Talal Foundations, Sultan Bin Abdulaziz Al-Saud Foundation, Saudi Industrial Development Fund, Abdul Latif Jameel Fund, Sulaiman Bin Abdul Aziz Al Rajhi Charitable Foundation, and Cooperative Associations. Based on the principles of the empowerment of Saudi women, Princess Seetah Bint AbdulAziz Award for Excellence in Social Work comes to shed light on the reality of programs and projects of Saudi women's empowerment.

\subsection{Previous studies}

Najm (2013) revealed the role of development institutions in the empowerment of Palestinian women; the results indicated an effective role of development institutions of social, educational, economic, political and health for women's empowerment programs. While Rahman \& Sultana (2012) emphasized the role of nongovernmental organizations and associations in the psychological, social and economic women empowerment. These organizations and associations have contributed to grant jobs for illiterate women. On the other hand, Khan and Bibi (2011) demonstrated the positive effects of a government run participatory development projects on the social and economic empowerment of women and its implications for poverty alleviation. Jabeen \& Jabeen (2013) focused on the importance of a legal role for the elimination of socio-customary practices, discrimination against women and patriarchal structure of society. Adesua-Lincoln (2011) showed that several of women entrepreneurs lacked information and counseling procedures for the funding sources of their projects. This is very serious constraint impacting of their business start-up. Al-Syouf (2007) showed the effectiveness of civil society organizations in women's empowerment programs in Jordan, furthermore, these organizations helped on the empowerment of women in the economic, social, political, and psychological aspects and to develop voluntary work. On the other hand, Al-Kharouf and Al-Hadidi (2011) agreed with Al-Syouf on the effectiveness of non-governmental development projects in the economic and social empowerment of Jordanian women. Awan (2012) also stressed the role of civil society in social, economic and political empowerment of women. He confirmed that the struggle of equal rights for women does not confine to socio-economic empowerment but this notion further extends to the equal political participation of women.

Al-Lamky (2006) pointed out the success of the initiative of the feminization of leadership in the Omani society through the appointment of women in positions of leadership and political terms, they are highly motivated and ambitious and that was the process of socialization, education and gender equality that major roles in parodies of these positions. Kemp (2013) offered the experience of United Arab Emirates (UAE) towards achieving the Millennium Development Goals (3) through the UAE government's strategy to increase women's empowerment access to education; and social acceptance of educated women. In Kingdom of Saudi Arabia, Danish and Smith (2012) explore the challenges facing female entrepreneurs. They establish and manage small and medium-sized enterprises of projects, in spite of the challenges of societal and institutional represented the financial resources, training, and traditional administrative procedures that require the representation of males in the establishment and funding of projects of Saudi businesswomen.

In a similar study of Danish and Smith, Itani, Sidani and Baalbaki (2011) noted the satisfaction of UAE female running their own businesses. Women explained that there are no conflicts between their work and their personal lives, but they face some obstacles at the startup of their venture, such as lack of support of the society, society traditions, and personal and family reasons. Prins (2008) found that the literacy programs for women and men have created more of self-confidence, self-esteem, the ability to participate in and influence new spaces, the ability to formulate and express ideas, and improve relationships with partners, parents, children, or other family members. On the other hand, Niraula (2011) revealed that the simply acquiring the ability to read and write skills can help the women to enhance their personal development.

In addition, Easton (2005) considered that literacy and empowerment are overlapping and intertwined in two ways, micro and macro. He defines the micro stage as psycho-cultural empowerment and the macro level as socio-economic empowerment, and argues that there is a physically powerful relation between literacy and empowerment which deals with social, economic, cultural and psychological aspects of learners Kannoush and Ghawnmeh (2011) stressed the significance of feminist Quota in the Jordanian election system to the improvement of women in the society and to ensure their participation in making political decisions. Women will then be capable of attracting public opinion and convincing the masses of their capacity to represent them, and also capable of introducing programs that satisfy citizens ambitions in general. 
Balol (2009) confirmed that the political participation of Arab women is below the required level, and despite the progress witnessed by the status of Arab women in the areas of health and education, these gains have not been matched by similar achievements in the political field. Furthermore, the share of women participating in public and political life in the Arab region is among the lowest quota in the regions of the world. Kafarna and Salem (2011) indicated the role of the parliamentary elections in the political empowerment of Jordanian women through the promotion of self-confidence; giving them some political skills and participation in the Council of Representatives. In contrast, Alissa (2008 showed a positive attitudes and acceptance among the Saudi society in political participation of women. While Jibran (2008) showed the existence of obstacles that faced the participation of women's Yemeni in the elections. He indicated that there are negative effects of the positions of the religious people for women's participation in elections, by the nomination or election.

After reviewing the theoretical framework and previous studies of women's empowerment programs, this study comes to shed light on empowerment programs for divorced, widows and spinsters women .Since the previous studies don't focus on this topic, this study will add something new and fill the gap in this topic.

\subsection{Participants}

\section{METHOD}

The population of the study consisted of all employees GNGIA in Najran, Kingdom of Saudi Arabia. However, the sample of the study were selected randomly that consisted of (78) employees, (male $=60$, female $=18$ ) working in (12) GNGIA in Najran.

\subsection{Instrument}

For the purpose of this study, a questionnaire was developed to identify the role of governmental and non-governmental institutions and associations on women's empowerment. The initial version of the questionnaire was modified by experts from the members of College of Education, Najran University. However, the final draft of the questionnaire consisted of (46) items, which distributed into four domains: educational empowerment, social empowerment, economic empowerment, and political empowerment. Therefore, FivePoint Likert Scale was used. For the purpose of analyzing the results of the study, the questionnaire has been classified into three levels (low, average, and high). The three levels become as follows: 1-2.33 (low level), 2.34-3.67 (average level), and 3.68-5 (high level). In addition, to examine the internal consistency reliability of the questionnaire, the Cronbach's Alpha formula was calculated, the reliability coefficient of whole items of the questionnaire was $(r=.83)$. The high reliability coefficient indicates that the questionnaire has high internal consistency

III.

RESULTS

\subsection{Results related to the first question:}

"What is the role of governmental and non-governmental institutions and associations on women's empowerment"? Means and standard deviations are computed. Table 1 illustrates the results

Table 1: Means and standard deviations of women's empowerment

\begin{tabular}{|l|c|c|c|}
\hline \multicolumn{1}{|c|}{ Domain } & N & Mean & SD \\
\hline Social empowerment & 78 & 1.92 & .165 \\
\hline Economic empowerment & 78 & 1.89 & .152 \\
\hline Political empowerment & 78 & 1.88 & .214 \\
\hline Educational empowerment & 78 & 1.87 & .232 \\
\hline
\end{tabular}

Table 1 shows the means between (1.92-1.87), where the social empowerment comes in the first rank $(\mathrm{M}=1.92)$, while the educational empowerment comes in the last rank $(\mathrm{M}=1.87)$.

\subsection{Results related to the second question:}

"Are there any differences in the role of governmental and non-governmental institutions and associations on women's empowerment due to gender"? Means, standard deviations and t-test formula are computed. Table 2 illustrates the results

Table 2: Means, standard deviations and t-test of women's empowerment according to gender

\begin{tabular}{|c|c|c|c|c|c|c|}
\hline Domain & Gender & $\mathbf{N}$ & Mean & SD & F & Sig. \\
\cline { 1 - 7 } Social empowerment & Male & 60 & 1.93 & .158 & \multirow{2}{*}{.287} & .237 \\
\cline { 2 - 6 } & Female & 18 & 1.87 & .184 & & .237 \\
\hline
\end{tabular}


The Role of Governmental and Non-Governmental Institutions and Associations on Women's

\begin{tabular}{|c|c|c|c|c|c|c|}
\hline \multirow[t]{2}{*}{ Economic empowerment } & Male & 60 & 1.89 & .141 & \multirow{2}{*}{1.82} & \multirow{2}{*}{.816} \\
\hline & Female & 18 & 1.88 & .188 & & \\
\hline \multirow[t]{2}{*}{ Political empowerment } & Male & 60 & 1.87 & .204 & \multirow{2}{*}{1.29} & \multirow{2}{*}{.444} \\
\hline & Female & 18 & 1.92 & .246 & & \\
\hline \multirow[t]{2}{*}{ Educational empowerment } & Male & 60 & 1.88 & .222 & \multirow{2}{*}{2.54} & \multirow{2}{*}{.307} \\
\hline & Female & 18 & 1.82 & .264 & & \\
\hline
\end{tabular}

Table 2 illustrates that there are no statistically significant differences in the role of governmental and non-governmental institutions and associations on women's empowerment due to gender, the value of $\mathrm{F}$ on the domains of women's empowerment (social, economic, political, educational) are not statistically significant at $\mathrm{p}$ $\leq .05$.

\subsection{Results related to the third question:}

"Are there any differences in the role of governmental and non-governmental institutions and associations on women's empowerment due to the type of institutions or associations"? Means, standard deviations and t-test formula are computed. Table 3 illustrates the results.

Table 3: Means, standard deviations and t-test of women's empowerment according to the type of institutions or associations

\begin{tabular}{|c|c|c|c|c|c|c|}
\hline Domain & Type & $\mathbf{N}$ & Mean & SD & $\mathbf{F}$ & Sig. \\
\hline \multirow[t]{2}{*}{ Social empowerment } & Governmental & 45 & 1.93 & .167 & \multirow{2}{*}{.124} & \multirow{2}{*}{.510} \\
\hline & Non-Governmental & 33 & 1.90 & .163 & & \\
\hline \multirow[t]{2}{*}{ Economic empowerment } & Governmental & 45 & 1.89 & .149 & \multirow{2}{*}{.050} & \multirow{2}{*}{.719} \\
\hline & Non-Governmental & 33 & 1.90 & .157 & & \\
\hline \multirow[t]{2}{*}{ Political empowerment } & Governmental & 45 & 1.90 & .220 & \multirow{2}{*}{.603} & \multirow{2}{*}{.441} \\
\hline & Non-Governmental & 33 & 1.86 & .207 & & \\
\hline \multirow[t]{2}{*}{ Educational empowerment } & Governmental & 45 & 1.85 & .211 & \multirow{2}{*}{1.22} & \multirow{2}{*}{.625} \\
\hline & Non-Governmental & 33 & 1.88 & .261 & & \\
\hline
\end{tabular}

Table 3 explains that there are no statistically significant differences in the role of governmental and non-governmental institutions and associations on women's empowerment due to type of institutions or associations, the value of $\mathrm{F}$ on the domains of women's empowerment (social, economic, political, and educational) and these values are not statistically significant at $\mathrm{p} \leq .05$.

\section{DISCUSSION}

The purpose of this study is to identify the role of GNGIA on Saudi's women empowerment. The results in general pointed to a weakness of the contribution of GNGIA in the empowerment programs and projects that oriented for divorced, widows and spinsters women in the region of Najran. The following is a discussion of the results for each area of empowerment:

\subsection{Educational empowerment}

The results indicated a weakness the contribution of GNGIA in the educational empowerment of divorced, widows and spinsters women. This can be attributed to the lack of empowerment programs of education which geared to these women in the region of Najran, where does not have courses, training and workshops in order to empower women in the areas of literacy, lack of development of self-learning skills, lack of programs to support women's rights in education, lack of career and counseling programs and lack of skills of development programs in ICT.

\subsection{Social empowerment}

The results indicated a weakness in the contribution of GNGIA in the social empowerment of divorced, widows and spinsters women. This can be attributed to the lack of programs and projects of social empowerment offered by these institutions and associations in Najran. In these GNGIA there are no programs gain women skills of self-management, planning for the future, decision-making within the family, and methods the socialization of children. It also does not have programs about family counseling, marital counseling, regulations the work of women, reproductive health and other programs to promote a culture of volunteerism 
and community service. No programs in these institutions and associations that focus on some social negative issues such as early marriage, violence and discrimination against women and their right in inheritance.

\subsection{Economic Empowerment}

The results indicated a weakness in the contribution of GNGIA in the economic empowerment of divorcees and widows and spinsters women. This can be attributed to the lack of economic programs and projects offered by these institutions and associations in Najran. Moreover, GNGIA only provide cash money as a kind of support for women. Besides, the GNGIA do not have the programs and projects that are interested in the economic empowerment of women such as: labor rights, the establishment and management of small projects, training programs on certain professions such as sewing, cosmetics, fashion, programs to lead women to sources of financial support for small projects, programs to improve the level of living and employment opportunities for women in Najran.

\subsection{Political Empowerment}

The results indicated a weakness in the contribution of GNGIA in the political empowerment of divorcees and widows and spinsters women in Najran. This can be attributed to the lack of seminars, lectures, conferences and workshops offered by these institutions and associations that highlighting their political rights, programs to encourage women to participate in elections, the right to vote and run for municipal councils, and programs of vocational rehabilitation programs. In addition, the weakness of the contribution of the GNGIA in organizing programs that shows the importance of the participation of women in the Council of Shura, civil society organizations and cooperative societies.

Nikkhah et al (2011) emphasized the role of non-governmental organizations in women's empowerment programs. These organizations played an essential responsibility to support the community for improving their lives and situations. Nikkhah et al believed that the women's empowerment is a key strategy to development process. According to Islam and Sultana (2005) showed that the fundamental objective of the GNGIA are empowering the powerless women to discover their potentialities in order to help them to participate in the socio-economic development to improve their situation in society. On the other hand, Panda (2007) indicated that the mobilizing people to join in projects are another essential strategy adopted by GNGIA. They not only promote people to participate in the activities and programs carried out by them, but also to find the sources of cash as a kind of support. Furthermore, Najm (2013), Rahman and Sultana (2012), Al-Syouf (2007), Al-Kharouf and Al-Hadidi (2011) and Al-Louzi (2010) indicated the effectiveness of GNGIA and civil society organizations of social, educational, economic and political women's empowerment programs.

Al-Esseily (2012) pointed out the importance of activating women's empowerment through improving their education programs by giving special courses to women and preparing cultural programs to enhance selfconfidence to enable them to get senior leadership positions. Edwan agreed with Al-Darasy that cited in (AlEsseily, 2012) to the existence of government policies in Saudi Arabia that supports the economic empowerment of women. But there are weaknesses in the participation of Saudi women in economic policymaking, the lack of their own training programs for women in the field of investment, marketing, and project management. Thus, the social restrictions and governmental actions are considered an obstacle to the low participation of women in the labor market.

Al-Sayegh (2013) considered the customs, traditions and social values a weaken in the participation of Saudi's women in the centers of political decision-making; furthermore, there is no legislation and laws regulating the contributions of women in policy-making. They also believe in spite of the existence of these obstacles and barriers, that there are other areas that have emerged women, especially in the fields of literary, cultural and educational. Al-Mmberek (2013) emphasized the weakness of contribution of Saudi's women in the labor market as compared with some of the Cooperation Council for the Arab State of the Gulf, the work of women in the Saudi labor market is characterized not only in the limited opportunities, but it also extends the limited opportunities for promotion to take over management or leadership positions. Whether, the empowerment of women particularly in respect of education, health and economic opportunities, are highly important ends in themselves. It also enhances their decision-making ability, knowledge, skills and selfconfidence to be full partners in the developmental process (Vijayanthi, 2002).

\section{CONCLUSION}

This is the study maybe one of the few studies - within the limits of informed researchers - which deals with educational, social, economic and political empowerment programs of divorced, widows and spinsters women in Saudi Arabia generally and in the region of Najran particularly. The results demonstrated that there are weaknesses in the shortening and empowerment programs for women in Najran in general and empowerment programs targeted for divorced, widows and spinsters women in particular. Based on the results of this study, it is crucial for GNGIA to activate women's empowerment programs and to highlight the role and 
influential in the development of political, economic, social and cultural as they constitute half of the society. In order to activate these programs and projects in Saudi society it must be the establishment of associations of women or the establishment of a High Council for Women's Affairs in Saudi Arabia. However, this Council should highlight the role of women in Saudi society through the establishment of conferences, seminars and lectures that will contribute to the empowerment of women in all fields of life. Whereas, the work of these associations or council confined to major cities, but must be extended to all areas of the Kingdom. It can justify the weak contribution of institutions and associations in Najran in the programs and projects of the women's empowerment to the nature of society at Najran. It is a society adheres to the customs and traditions. Consequently, the social customs and traditions could reduce women's participation in the programs and projects of empowerment.

\section{ACKNOWLEDGEMENTS}

Our special thanks go to the employees of the institutions and associations in the region of Najran, Dr.

Mansour Bin Nayef Al-Otaibi and faculty members at School of Education, Najran University.

\section{REFERENCES}

[1] Abdel Jawad, S. (2009). Use empowerment strategy to help breadwinner's women to face her problems. Journal of Studies in Social and Human Sciences, 4,(26),1753.

[2] Adesua-Lincoln, A. (2011) Assessing Nigerian female entrepreneur's access to finance for business start-up and growth. African Journal of Business Management, 5, (13), 5348-5355.

[3] Ahmed, A \& Khalid, M. (2012). Construction of contemporary women in soap operas. Global Media Journal, 3, (1), 1-9.

[4] Al-Esseily, R. (2012). The Contribution of Open University Education in empowering young women. Palestinian Journal of Open Education, 3, (6), 75-114.

[5] Alissa, B. (2008). The political participation of Saudi women from the perspective of citizens, MA Thesis, Yarmouk University, Jordan.

[6] Al-Kharouf, A \& Al-Hadidi, S. (2011). Izdihar women development project and its role in the empowerment of Jordanian women. Dirasat: Human and Social Sciences, 38, (1), 240-267.

[7] Al-Lamky, A. (2006). Feminizing leadership in Arab societies: the perspectives of Omani female leaders. Women in Management Review, 22, (1), 49-67.

[8] Al-Louzi, S. (2010). Empowering illiterate females through community organization. Mutah Journal for research and studies, 25, (6), 9-26.

[9] Al-Mmberek, W. (2013). An exploratory study of the private sector attitudes towards women part-time work in Saudi Arabia. Arab Journal of Management, 33,1 ,

[10] Al-Sayegh, N. (2013). Proposed strategy for the participation of Saudi women in decision-making process. Arab Studies in Education \& Psychology, 2, (37), 13-56.

[11] Al-Syouf, N. (2007). Civil society organizations and social change: A study of the efficiency of Jordanian women's empowerment programs. Master thesis, University of Jordan.

[12] Arum, I. (2010). Women NGO's and women empowerment in Nigeria. African Research Review, 4, (3), 272-280.

[13] Awan, S. (2012). Role of civil society in empowering Pakistani women. A Research Journal of South Asian Studies, 27, (2), 439458.

[14] Balol, S. (2009). Political empowerment of Arab women between decisions and international trends. Journal of Economic and Legal Sciences, 25, (2),645-686.

[15] Bukhari, S., \& Asim, M. (2013).Women empowerment in a Muslim society: A practical observation. Interdisciplinary Journal of Contemporary Research in Business, 5, (1), 768-778.

[16] Charmus, J \& Wieringa, S. (2003). Measuring Empowerment: An Assessment of the Gender Related Development Index and the Gender Empowerment Measure. Journal of Human Development and Capabilities, 4, (3), 419-435.

[17] Danish, A \& Smith, H. (2012). Female entrepreneurship in Saudi Arabia: opportunities and challenges. International Journal of Gender and Entrepreneurship, 4, (3), 216-235.

[18] Dito, M. (2013). Challenges facing Women's Empowerment in the Arab world. Paper presented at the Conference of women's issues and challenges of the era, 20-21November 2013, Kingdom of Bahrain.

[19] Drower, S. (2005).Group work to facilitate empowerment in the context of HIV/AIDS. Cape Town: Oxford University press.

[20] Easton, P. (2005). Literacy and empowerment: Raising Key Issues. Paper presented at the Sixth Meeting of the Working Group on Education for All, UNESCO, 19-21 July 2005.

[21] Fatany, S. (2007). Saudi Women towards a New Era. Kingdom of Saudi Arabia: Ghainaa Publication.

[22] Floyd, R. (2005). Empowerment. New York: Roger W. Floyd.

[23] Islam N, Sultana N. (2005). Role of NGOs in empowering the vulnerable women: A study on ACD. Asian Affairs, 27, (4), 24-40.

[24] Itani, H., Sidani, Y., \& Baalbaki, I. (2011). United Arab Emirates female entrepreneurs: motivations and frustrations. Equality Diversity and Inclusion: An International Journal, 30, (5), 409-424.

[25] Jabeen, F \& Jabeen, M. (2013). Women empowerment and socio-economic development: a case study of Pakistan. European Journal of Business and Social Sciences, 1, (10), 113-116.

[26] Jibran, S. (2008). The obstacles to women's participation in elections in Yemen. Journal of Sociology, 15, (2), 68-88.

[27] Kafarna, A \& Salem, R. (2011). The role of the parliamentary elections in the political empowerment of Jordanian women. Journal of Al-Aqsa University, 15, (2), 154-187.

[28] Kannoush, M \& Ghawnmeh, N. (2011). The feminist Quota in the Jordanian election system from Jordanian women's perspective. Abhath Al-Yarmouk "Hum. \& Soc. Sci, 27, (1), 659-680.

[29] Kemp, L. (2013). Progress in female education and employment in the United Arab Emirates towards Millennium Development Goal (3): gender equality. Foresight, 15, (4), 264-277. 
[30] Khan, A \& Bibi Z. (2011). Women's socio-economic empowerment through participatory approach. Pakistan Economic and Social Review, 49, (1), 133-148.

[31] Mosedal, S. (2005). Assessing women's empowerment: Towards a conceptual framework. Journal of International Development, $17,(2), 243-257$

[32] Moyle, T., Dollard, M., \& Biswas, S. (2006). Personal and economic empowerment in rural Indian women: A self-help group approach. International Journal of Rural Management, 2, (2), 245-266.

[33] Najm, M. (2013). The role of development institutions in the empowerment of Palestinian women. The Islamic university journal of educational and psychology Studies, 21, (3), 239-276.

[34] Narayan, D. (2002). Empowerment and poverty reduction. Washington, DC: The World Bank.

[35] Nikkhah, H., Redzuan, M., \& Abu-Samah, A. (2010). The effect of women's socio-demographic variables on their empowerment. Journal of American Science, 6, (11), 426-434.

[36] Nikkhah,H., Redzuan., M,. \& Abu-Samah, A. (2011). The effect of Non-Governmental Organizations (NGO)'s approaches on women's empowerment in Shiraz, Iran. Journal of Human Ecology, 34, (3), 179-187.

[37] Niraula, A. (2011). Rethinking the role of literacy programs in women's empowerment. Master Thesis, University of Bergen.

[38] Oyelude, A \& Bamigbola, A. (2012). Women empowerment through access to information: the strategic roles of Non-governmental organizations in Nigeria. Paper presented at the IFLA World Library and Information Congress, 11-17 August 2012, Helsinki, Finland.

[39] Panda, B. (2007). Top down or bottom up? A study of grassroots NGOs' approach. Journal of Health Management, 9, (2), $257-273$.

[40] Panigrahy, R. (2006). Women Empowerment. New Delhi: Discovery Publishing House.

[41] Prins, E. (2008). Adult literacy education, gender equity and empowerment. Studies in the Education of Adults, 40, (1), 24-39.

[42] Rahman, S \& Sultana, N. (2012). Empowerment of women for social development. Journal of Arts, Science and Commerce, 3, (1), $50-59$.

[43] Sahbani, S, \& Abbas, H. (2013). Policies of empowerment and advancement of their situation highlighted addresses stage: King Abdullah triumph for women. Okaz Newspaper, N (4304), 30 March / 2013.

[44] Suja, S. (2012). Women empowerment through self-help group-anevaluative study. Sona Global Management Review, 6, (3), 68-82.

[45] Vijayanthi, K. (2002). Women's empowerment through self-help groups: A participatory approach. Indian Journal of Gender Studies, 9, (3), 263-274.

[46] Weinberger, K. (2001). Women's participation in local organizations: conditions and constraints. World Development, 29, (8), 13911404. 